\title{
Pengaruh Obesitas terhadap Kejadian Diabetes Mellitus pada Wanita Usia Subur di RSUD Dr. Djoelham Binjai Tahun 2017
}

\author{
Effect of Obesity on The Incidence of Diabetes Mellitus in Fertile Age \\ Women in RSUD Dr. Djoelham Binjai in 2017
}

\author{
Tika Ayu Pratiwi*1, Rahayu Lubis², Erna Mutiara ${ }^{3}$ \\ ${ }^{1}$ Program Studi S2 Ilmu Kesehatan Masyarakat, Universitas Sumatera Utara \\ ${ }^{2,3}$ Fakultas kesehatan masyarakat, Universitas Sumatera Utara \\ *Korespondensi Penulis: pratiwiayu1992@gmail.com
}

\begin{abstract}
Abstrak
Diabetes mellitus (DM) merupakan penyakit degeneratif yang paling umum ditemukan, peningkatan BMI (Body Mass Index) 1 angka akan mempunyai kecenderungan menjadi kencing manis sebesar 25\%. Dengan bertambahnya ukuran lingkaran perut dan panggul, terutama pada obesitas tipe sentral atau androit, menimbulkan resistensi insulin, suatu keadaan dimana insulin tidak dapat bekerja dengan baik, maka terjadilah kencing manis. Tujuan penelitian untuk melihat pengaruh obesitas terhadap kejadian diabetes mellitus pada wanita usia subur di RSUD DR. Djoelham Binjai tahun 2017. Penelitian ini menggunakan studi analitik observasional dengan desain studi unmatched case control. sampel dalam penelitian ini 52 orang (kasus) dan 52 orang (kontrol). Analisis data dilakukan dengan tahapan analisis univariat, bivariat dengan uji chi-Square. Pada kelompok kasus terdapat sebanyak 27 orang $(51,9 \%)$ wanita usia subur yang obesitas, dan 25 orang $(48,1 \%)$ yang tidak obesitas. Sedangkan pada kelompok kontrol terdapat sebanyak 14 orang $(26,9 \%)$ wanita usia subur yang obesitas, dan 38 orang $(73,1 \%)$ wanita usia subur yang tidak obesitas. Hasil uji statistik menunjukkan bahwa terdapat pengaruh obesitas terhadap kejadian diabetes mellitus ( $p=0,009)$ pada taraf nyata $\alpha=0,05$. Hasil penelitian juga menunjukkan nilai $\mathrm{OR}=$ $2,931(95 \%$ CI 1,292-6,652), artinya wanita usia subur yang obesitas perkiraan risikonya 2,9 kali akan menderita diabetes mellitus dibanding dengan yang tidak obesitas. Kesimpulan dan saran penderita diabates mellitus diharapkan dapat menjaga gula darah agar tetap dalam keadaan normal, mengurangi berat badan bagi pasien obesitas, mengatur kebiasaan makan yang memiliki tinggi karbo, mengurangi makanan yang mengandung tinggi lemak, serta memperbanyak mengkonsumsi sayur dan buah, dan melakukan aktifitas olah raga untuk mengurangi risiko terjadinya diabates mellitus.
\end{abstract}

Kata kunci: diabetes mellitus, obesitas

\section{Abstract}

Diabetes mellitus (DM) is the most common degenerative disease, an increase in BMI (Body Mass Index) 1 number will increase to 25\%. With the increase in the size of the abdominal and pelvic circumference, most of obesity is central or androit type, affecting insulin, a condition in which insulin cannot work properly, so diabetes occurs. Diabetes mellitus in women of suburban age at the DR. Djoelham Binjai in 2017. This study uses observational analytic studies with unrivaled case study designs. the sample in this study were 52 people 
(cases) and 52 people (controls). Data analysis was carried out by univariate, bivariate analysis with the chi-square test. In the case group there were 27 people (51.9\%) women of childbearing age, and 25 people (48.1\%) were not obese. While in the control group as many as 14 people (26.9\%) women of childbearing age, and 38 people (73.1\%) women of childbearing age are not obese. The results of statistical tests showed that there were differences in diabetes mellitus $(p=0.009)$ at the real level $\alpha=0.05$. The results also showed $O R=2,931$ (95\% CI 1,292-6,652), meaning that women of childbearing age who are obese estimate the risk of 2.9 times diabetes mellitus compared to those who are not obese. The conclusions and suggestions of people with diabetes mellitus are expected to be able to contain blood sugar in normal conditions, reduce weight for obese patients, eat lots of carbo, reduce foods that contain lots of fat, and increase eating vegetables and fruits, and do sports activities diabates mellitus.

Keywords: diabetes mellitus, obesity

\section{PENDAHULUAN}

Diabetes mellitus merupakan kelainan metabolisme yang kronis terjadi defisiensi insulin atau retensi insulin, ditandai dengan tingginya keadaan glukosa darah (hiperglikemia) dan glukosa dalam urine (glukosuria) atau merupakan sindroma klinis yang ditandai dengan hiperglikemia kronik dan gangguan metabolisme karbohidrat, lemak dan protein sehubungan dengan kurangnya sekresi insulin secara absolut/relatif dan atau adanya gangguan fungsi insulin (Maryunani, 2013).

Secara umum penyakit ini dibagi atas dua tipe, yaitu tipe I dan tipe II. DM tipe II menempati lebih dari 90\% kasus di negara maju. Di negara sedang berkembang, hampir seluruh diabetesi tergolong sebagai penyandang DM tipe II $40 \%$ diantaranya terbukti berasal dari kelompok masyarakat yang terlanjur menggubah gaya hidup tradisional menjadi “modern" (Arisman, 2013).

Diabetes melitus Tipe 2 sebelumnya dinamakan diabetes yang timbul dimasa dewasa, karena kebanyakan timbulnya pada usia lebih dari 40 tahun. Namun pada masa sekarang ini orang yang lebih muda juga dapat menyandang diabetes mellitus tipe 2, banyak faktor yang menyebabkan kejadian diabetes melitus, selain faktor keturunan, faktor lingkungan juga sangat berpengaruh terhadap timbulnya diabetes. (Waspadji, 2012).

Wanita Usia Subur (WUS) merupakan wanita dengan usia 15-49 tahun. Puncak kesuburan wanita terjadi pada rentang usia 20-29 tahun. Wanita memiliki risiko yang cukup besar terhadap diabates melitus tipe 2. Jika dilihat dari faktor risiko, wanita lebih berisiko mengidap diabetes karena secara fisik wanita memiliki peluang peningkatan indeks masa 
tubuh yang lebih besar. Sindroma siklus bulanan (premenstrual syndrome) dan pascamenopouse yang membuat distribusi lemak tubuh menjadi mudah terakumulasi. Selain itu, pada wanita yang sedang hamil terjadi ketidakseimbangan hormonal. Hormon progesteron menjadi tinggi sehingga meningkatkan sistem kerja tubuh untuk merangsang sel-sel berkembang, sehingga terjadi peningkatan kadar gula darah saat kehamilan. Akibat proses hormonal tersebut sehingga wanita berisiko menderita diabetes melitus tipe 2 (Irawan, 2010).

Menurut International Diabetes Federation (IDF) tahun 2012, jumlah penderitanya semakin bertambah. lebih dari 300 juta orang di seluruh dunia mengidap diabetes mellitus, dan sekitar 60 juta dari mereka adalah perempuan usia reproduksi (15-49) tahun.

Wanita lebih rentan menderita penyakit kronis seperti diabetes dan menderita cacat dibandingkan dengan laki-laki. Diperkirakan tahun 2015-2050 bahwa mayoritas kasus diabetes melitus terjadi pada wanita. Menurut Dinas Kesehatan Task Force Amerika Serikat, masalah Diabetes pada wanita merupakan masalah yang sangat penting, karena terdapat kaitan antara kehamilan dengan kejadian diabetes melitus (CDC, 2011).

Indonesia merupakan negara kedua terbesar setelah India yang mempunyai penderita diabetes mellitus terbanyak yaitu 8.426.000 orang di tingkat Asia Tenggara, dan diperkirakan meningkat menjadi 21.257.000 pada tahun 2030. pada tahun 2011 indonesia berada pada peringkat 10 negara dengan penderita diabetes mellitus terbanyak (usia 20-79 tahun), mencapai 7,3 juta orang.

Berdasarkan Riskesdas 2013, prevalensi penduduk usia $\geq 15$ tahun di indonesia sebesar $2.0 \%$ pada penduduk daerah perkotaan. Dalam laporan riskesdas tahun 2013 ini tidak disebutkan prevalensi diabetes mellitus pada wanita usia subur (15-49) tahun, berarti belum ada laporan nasional yang melaporkan kejadian DM pada rentang usia subur.

Berdasarkan Riskesdas 2013 didapat bahwa prevalensi diabetes mellitus di Sumatera Utara sendiri prevalensi diabetes mellitus sebesar 1,8\%. Dengan persentase nasional adalah 1,5\%. Prevalensi diabetes mellitus ini meningkat sesuai dengan bertambahnya umur $\geq 45$ tahun, dan juga cenderung lebih tinggi pada masyarakat dengan tingkat pendidikan tinggi (D1, D3 dan PT) sebesar 2,5\%, dengan kuintil indeks kepemilikan tinggi sebesar 2,6\%. Berdasarkan Riskesdas Sumatera Utara Tahun 2007 prevalensi diabetes di Kota Binjai adalah 0,8\% lebih tinggi jika dibandingkan dengan angka diabetes untuk wilayah Sumatera Utara 0,7\%. Berdasarkan data Dinas Kesehatan Kota Binjai wanita yang mengalami diabetes 
mellitus 1.127 orang dan wanita usia subur yang mengalami diabetes mellitus sebanyak 247 orang.

IDF tahun 2012 menyebutkan bahwa faktor risiko untuk diabetes tipe 2 (dua) adalah kegemukan, diet dan aktivitas fisik, meningkatnya usia, resistensi insulin, riwayat keluarga diabetes, dan etnis. Perubahan diet dan aktivitas fisik yang berkaitan dengan pesatnya urbanisasi telah menyebabkan peningkatan tajam pada penderita diabetes. Wanita hamil yang memiliki berat badan berlebih telah dan memiliki riwayat keluarga diabetes berisiko tinggi terkena diabetes gestasional (GDM)

IDF tahun 2012 menyebutkan bahwa faktor risiko untuk diabetes tipe 2 (dua) adalah kegemukan, diet dan aktivitas fisik, meningkatnya usia, resistensi insulin, riwayat keluarga diabetes, dan etnis. Perubahan diet dan aktivitas fisik yang berkaitan dengan pesatnya urbanisasi telah menyebabkan peningkatan tajam pada penderita diabetes.

Perempuan yang memiliki lemak berlebih pada batang tubuh, terutama jika itu berada pada bagian perut, lebih mungkin terkena DM, ini dikarenakan lemak pada organ-organ perut lebih mudah diolah untuk memperoleh energi. Pada saat lemak diolah menjadi energi, kadar asam lemak dalam darah meningkat. Tingginya asam lemak dalam darah menyebabkan meningkatnya resistensi terhadap insulin (Ramaiah, 2008)

Orang gemuk dengan BMI di atas 25, tiap peningkatan BMI (Body Mass Index) 1 angka akan mempunyai kecenderungan menjadi kencing manis sebesar 25\%. Dengan bertambahnya ukuran lingkaran perut dan panggul, terutama pada obesitas tipe sentral atau androit, menimbulkan resistensi insulin, suatu keadaan dimana insulin tidak dapat bekerja dengan baik, maka terjadilah kencing manis (Manganti, 2012), hal ini sejalan dengan penelitian yang dilakukan oleh Yanita dan Kurniawaty (2016), di dapati hasil analisis didapatkan obesitas dengan $\mathrm{p}=0,001$, umur dengan $\mathrm{p}=0,001$, merokok dengan $\mathrm{p}=0,008$ dan aktivitas olahraga dengan kejadian DM tipe 2. Berdasarkan penelitian ini dapat disimpulkan bahwa pasien dengan obesitas dapat meningkatkan risiko DM Tipe 2. Oleh karena itu kejadian obesitas di masyarakat perlu diturunkan dengan memperbaiki gaya hidup dan pola makan masyarakat.

Dengan kemajuan zaman, membuat manusia semakin terdorong dengan gaya hidup modern yang tidak sehat. Kesibukan mereka membuat tidak ada waktu untuk berolahraga, akibatnya, sirkulasi darah dalam tubuh tidak normal. Kerja jantung punikut terganggu sehingga secara keseluruhan kerja organ tubuh pun terganggu, termasuk sensivitas insulin. 
Selain itu, mereka yang terbiasa mengonsumsi makanan instan atau makanan cepat saji yang banyak mengandung garam dan penyedap rasa. Kandungan ini bila di konsumsi rutin dan tidak diimbangi dengan pola hidup yang sehat, akan menyebabkan terganggunya kesehatan, seperti kegemukan, kolesterol,dan lain-lain. Inilah yang memicu terganngunya metabolisme dalam tubuh, termasuk sensivitas insulin yang menyebabkan DM (Susilo dan Wulandari, 2011).

Namun, yang banyak terjadi di masyarakat kita adalah lalai terhadap investasi tubuh itu sendiri. Bahkan WHO memastikan peningkatan penderita DM tipe II paling banyak akan terjadi di negara-negara berkembang termasuk indonesia. Sebagian peningkatan jumlah penderita DM tipe II karena kurangnya pengetahuan tentang pengelolaan DM tipe II. Pengetahuan pasien tentang pengelolaan DM sangat penting untuk mengontrol kadar glukosa darah, kemudian dapat mengubah perilakunya, akan dapat mengendalikan kondisi penyakitnya sehingga dapat hidup lebih lama (Nurrahmani, 2012).

Berdasarkan Info Datin tahun 2014, pengendalian diabetes mellitus sudah dilakukan di pelayanan kesehatan seperti di puskesmas, posbindu PTM (Pos Pembinaan Terpadu Penyakit Tidak Menular) dan pelayanan kesehatan lainnya, namun angka kejadian diabetes mellitus masih saja meningkat. Dan anggapan masyarakat tentang penyakit diabetes merupakan penyakit tua dan merupakan penyakit keturunan, sehingga tidak mewaspadai akan penyakit ini. Padahal, penyakit ini bisa menyerang pada umur berapa saja jika kebiasaan makan dan gaya hidup yang tidak sehat dilakukan terus menerus.

Berdasarkan survei awal yang didapatkan dari pencatatan medik di RSUD DR.RM Djoelham Binjai, jumlah penderita diabetes mellitus pada wanita tahun 2017 yaitu rawat jalan 1.412 orang dan pada wanita usia subur 52 orang. Berdasarkan wawancara dengan 5 pasien. dari hasil wawancara tersebut pasien mengungkapkan bahwa 2 dari 5 pasien tersebut tidak memiliki riwayat keluarga menderita diabetes mellitus, 1 orang dari 5 pasien memiliki kebiasaan makan yang tidak teratur dan sering mengkonsumsi makanan cepat saji seperti KFC, burger dan 3 diantara 5 pasien tersebut memiliki berat badan yang berlebih (obesitas).

Berdasarkan Info Datin tahun 2014, pengendalian diabetes mellitus sudah dilakukan di pelayanan kesehatan seperti di puskesmas, posbindu PTM (Pos Pembinaan Terpadu Penyakit Tidak Menular) dan pelayanan kesehatan lainnya, namun angka kejadian diabetes mellitus masih saja meningkat. Dan anggapan masyarakat tentang penyakit diabetes merupakan penyakit tua dan merupakan penyakit keturunan, sehingga tidak mewaspadai akan penyakit 
ini. Padahal, penyakit ini bisa menyerang pada umur berapa saja jika kebiasaan makan dan gaya hidup yang tidak sehat dilakukan terus menerus.

Berdasarkan survei awal yang didapatkan dari pencatatan medik di RSUD DR.RM Djoelham Binjai, jumlah penderita diabetes mellitus pada wanita tahun 2017 yaitu rawat jalan 1.412 orang dan pada wanita usia subur 52 orang. Berdasarkan wawancara dengan 5 pasien. dari hasil wawancara tersebut pasien mengungkapkan bahwa 2 dari 5 pasien tersebut tidak memiliki riwayat keluarga menderita diabetes mellitus, 1 orang dari 5 pasien memiliki kebiasaan makan yang tidak teratur dan sering mengkonsumsi makanan cepat saji seperti KFC, burger dan 3 diantara 5 pasien tersebut memiliki berat badan yang berlebih (obesitas).

\section{METODE PENELITIAN}

Jenis penelitian yang digunakan adalah studi analitik observasional dengan desain studi Unmatched Case Control dengan memilih kasus yang menderita diabetes mellitus pada kelompok wanita usia subur dan kontrol yang tidak menderita diabetes mellitus pada kelompok wanita usia subur. Penelitian dimulai dengan mengidentifikasi pasien dengan diabetes mellitus (retrospektif) melalui survei dan pemeriksaan secara langsung kepada pasien. bertujuan untuk menganalisis faktor yang memengaruhi kejadian diabetes pada wanita usia subur. Penelitian ini telah dilaksanakan di RSUD DR.Djoelham Binjai. Pada bulan september - februari 2018.

Populasi dari penelitian ini adalah seluruh wanita usia subur yang telah didiagnosis menderita diabetes millitus maupun tidak menderita diabetes millitus yang datang berobat ke RSUD DR.Djoelham Binjai pada tahun 2018. Sampel kasus adalah wanita usia subur yang berobat ke RSUD DR.Djoelham yang menderita diabetes mellitus (total populasi) yaitu 52 orang dan dan sampel kontrol adalah wanita usia subur yang berobat ke RSUD DR.Djoelham Binjai tetapi tidak menderita diabetes mellitus.

Pengumpulan data menggunakan data primer dan sekunder. Pengumpulan primer dilakukan dengan wawancara menggunakan kuesioner, alat ukur yang digunakan adalah kuesioner sedangkan pengumpulan data sekunder dilakukan dengan mengambil data-data dari dokumen atau catatan yang diperoleh dari rekam medik RSUD DR.Djoelham Binjai tahun 2018. 


\section{HASIL DAN PEMBAHASAN}

a. Analisis Univariat

Tabel 1. Distribusi Frekuensi Karakteristik Penderita Diabetes Mellitus pada Wanita Usia Subur Di RSUD DR. Djoelham Binjai Tahun 2017

\begin{tabular}{|c|c|c|c|c|}
\hline \multirow{3}{*}{ Variabel } & \multicolumn{4}{|c|}{ KejadianDiabetes Mellitus } \\
\hline & \multicolumn{2}{|c|}{ Diabetes } & \multicolumn{2}{|c|}{ Tidak Diabetes } \\
\hline & n & $\%$ & $\mathbf{n}$ & $\%$ \\
\hline \multicolumn{5}{|l|}{ Riwayat Keluarga } \\
\hline Ada riwayat & 29 & 55,8 & 9 & 17,3 \\
\hline Tidak ada riwayat & 23 & 44,2 & 43 & 82,7 \\
\hline \multicolumn{5}{|l|}{ Obesitas } \\
\hline Obesitas & 27 & 51,9 & 14 & 26,9 \\
\hline Tidak obesitas & 25 & 48,1 & 38 & 73,1 \\
\hline \multicolumn{5}{|l|}{ Aktivitas fisik } \\
\hline Ringan & 31 & 59,6 & 19 & 36,5 \\
\hline Sedang & 21 & 40,4 & 33 & 63,5 \\
\hline \multicolumn{5}{|l|}{ Kebiasaan makan } \\
\hline Lebih & 35 & 67,3 & 21 & 40,4 \\
\hline Cukup & 17 & 32,7 & 13 & 59,6 \\
\hline \multicolumn{5}{|c|}{$\begin{array}{l}\text { Riwayat Melahirkan bayi } \geq \\
4000 \text { gram }\end{array}$} \\
\hline Ada riwayat & 15 & 28,8 & 6 & 20,2 \\
\hline Tidak ada riwayat & 37 & 71,2 & 46 & 79,8 \\
\hline
\end{tabular}

Tabel di atas menunjukkan distribusi frekuensi responden kejadian diabetes melitus pada pada wanita usia subur di RSUD DR.Djoelham Binjai, berdasarkan riwayat keluarga pada kelompok kasus sebanyak 29 orang $(55,8 \%)$ wanita usia subur ada riwayat keluargadan 23 orang $(44,2)$ tidak ada riwayat keluarga.Pada kelompok kontrol terdapat sebanyak 9 orang $(17,3 \%)$ yang tidak ada riwayat keluarga dan 43 orang $(82,7 \%)$ wanita usia subur tidak ada riwayat keluarga.

Berdasarkan obesitas pada kelompok kasus terdapat sebanyak 27 orang $(51,9 \%)$ wanita usia subur yang obesitas, dan 25 orang $(48,1 \%)$ yang tidak obesitas. Sedangkan pada kelompok kontrol terdapat sebanyak 14 orang $(26,9 \%)$ wanita usia subur yang obesitas, dan 38 orang $(73,1 \%)$ wanita usia subur yang tidak obesitas.

Tabel distribusi frekuensi aktivitas fisik menunjukkan bahwa pada kelompok kasus terdapat sebanyak 31 orang $(59,6 \%)$ wanita usia subur yang aktivitas fisik nya ringan, dan 21 orang $(40,4 \%)$ yang aktivitas fisiknya sedang dan berat. Sedangkan pada kelompok kontrol terdapat sebanyak 19 orang $(36,5 \%)$ wanita usia subur yang aktivitas fisik nya ringan, dan 33 orang $(63,5 \%)$ wanita usia subur yang aktivitas fisiknya sedang dan berat. 
Pada tabel di atas juga terlihat bahwa kebiasaan makan, pada kelompok kasus terdapat sebanyak 35 orang $(59,6 \%)$ wanita usia subur yang kebiasaan makan nya lebih, dan 17 orang $(32,7 \%)$ yang kebiasaan makannya cukup. Sedangkan pada kelompok kontrol terdapat sebanyak 21 orang $(40,4 \%)$ wanita usia subur yang kebiasaan makanya lebih

Diperoleh datariwayat melahirkan bayi $\geq 4000$ gram pada kelompok kasus terdapat sebanyak 15 orang $(28,8 \%)$ wanita usia subur yang ada riwayat melahirkan bayi $\geq 4000$ gram, dan 37 orang $(71,2 \%)$ yang tidak ada riwayat melahirkan bayi $\geq 4000$ gram. Sedangkan pada kelompok control terdapat sebanyak 6 orang $(20,2 \%)$ wanita usia subur ada riwayat melahirkan bayi $\geq 4000$ gram, dan 46 orang $(79,8 \%)$ wanita usia subur yang tidak ada riwayat melahirkan bayi $\geq 4000$ gram.

b. Analisis Bivariat

Analisis ini digunakan untuk melihat pengaruh, obesitas, terhadap kejadian diabetes mellitus pada wanita usia subur di RSUD DR Djoelham Binjai Tahun 2017, dengan menggunakan Chi square pada CI 95\% dan $\alpha=0,05$.

Tabel 2. PengaruhVariabel Independen (Riwayat Keluarga, Obesitas, Aktivitas Fisik,

Pola Makan, Riwayat Melahirkan Bayi $\geq 4000$ Gram), terhadap Kejadian Diabates Mellitus pada Wanita Usia Subur di RSUD. DR. Djoelham Binjai Tahun 2017

\begin{tabular}{|c|c|c|c|c|c|c|}
\hline \multirow{3}{*}{ Variabel Independen } & \multicolumn{4}{|c|}{ Diabates Mellitus } & \multirow{3}{*}{$\begin{array}{c}p \\
\text { value }\end{array}$} & \multirow{3}{*}{$\begin{array}{c}\text { OR } \\
95 \% C I\end{array}$} \\
\hline & \multicolumn{2}{|c|}{ Diabetes } & \multicolumn{2}{|c|}{$\begin{array}{c}\text { Tidak } \\
\text { Diabetes }\end{array}$} & & \\
\hline & $\mathbf{n}$ & $\%$ & $\mathbf{n}$ & $\%$ & & \\
\hline \multicolumn{6}{|l|}{ Obesitas } & \multirow{3}{*}{$\begin{array}{c}2,931 \\
1,292-6,652\end{array}$} \\
\hline Obesitas & 27 & 51,9 & 14 & 26,9 & 0,009 & \\
\hline Tidak obesitas & 25 & 48,1 & 38 & 73,1 & & \\
\hline
\end{tabular}

Pada kelompok kasus terdapat sebanyak 27 orang (51,9\%) wanita usia subur yang obesitas, dan 25 orang $(48,1 \%)$ yang tidak obesitas. Sedangkan pada kelompok kontrol terdapat sebanyak 14 orang (26,9\%) wanita usia subur yang obesitas, dan 38 orang $(73,1 \%)$ wanita usia subur yang tidak obesitas. Hasil uji statistik menunjukkan bahwa terdapat pengaruh obesitas terhadap kejadian diabetes mellitus $(p=0,009)$ pada taraf nyata $\alpha=0,05$. Hasil penelitian juga menunjukkan nilai $\mathrm{OR}=2,931(95 \% \mathrm{CI}$ 1,292-6,652), artinya wanita usia subur yang obesitas perkiraan risikonya 2,9 kali akan menderita diabetes mellitus dibanding dengan yang tidak obesitas. 
Berdasarkan hasil penelitian pengaruh obesitas terhadap kejadian diabetes mellitus diperolah hasil analisis bivariat menunjukkan nilai $(\mathrm{p}<0,05)$, artinya variabel obeistas berpengaruh terhadap kejadian diabetes mellitus pada wanita usia subur. Dari hasil uji statistik menunjukkan bahwa terdapat pengaruh obesitas terhadap kejadian diabetes mellitus diperoleh nilai $\mathrm{OR}=2,931(95 \% \mathrm{CI}$ 1,292-6,652), artinya wanita usia subur yang obesitas perkiraan resikonya 2,9 kali akan menderita diabetes mellitus dibanding dengan yang tidak obesitas.

Hal ini sejalan dengan penelitian yang dilakukan Ravangard (2017) pada 504 WUS, $135(26,8 \%)$ melakukan skrining diabetes awal. Wanita dengan obesitas yang melakukan skrining awal berusia lebih tua dan mempunya body mass index yang lebih tinggi.

Kegemukan mempunyai risiko menyandang diabetes. Kegemukan dengan bentuk buah pear (lingkar perut lebih kecil dari lingkar pinggul) mempunyai risiko lebih rendah untuk menyandang diabetes dari pada kegemukan dengan bentuk buah apel (lebih besar lingkar perut dari pada lingkar pinggul). Penyebab yang persis dari perbedaan ini tidak diketahui, mungkin ada hubungannya dengan aktivitas metabolik jaringan lemak pada area tubuh yang berbeda. Pada obesitas abdominal (viseral), lemak yang tertimbun di sekitar abdomen tengah berhubungan dengan resistensi insulin dan diabetes (Yunir, 2015).

\section{KESIMPULAN}

Berdasarkan hasil penelitian yang telah dilakukan mengenai pengaruh obesitas terhadap kejadian diabetes mellitus pada wanita usia subur di RSUD DR. Djoelham Binjai, dapat disimpulkan bahwa terdapat pengaruh obesitas terhadap kejadian diabetes mellitus pada wanita usia subur di RSUD DR. Djoelham Binjai dengan nilai p 0,009 $(<0.05)$.

\section{SARAN}

1. Bagi rumah sakit perlu di adakan suatu penyuluhan untuk meningkatkan penegtahuan tentang penyakit diabetes mellitus yang meliputi faktor-faktor penyebab diabates mellitus, gejala diabates mellitus, komplikasi diabates mellitus, dan cara pencegahan diabates mellitus dengan cara membagikan leaflet kepada penderita diabets mellitus.

2. Bagi penderita diabates mellitus diharapkan dapat menjaga gula darah agar tetap dalam keadaan normal, mengurangi berat badan bagi pasien obesitas, mengatur kebiasaan makan yang memiliki tinggi karbo, mengurangi makanan yang mengandung tinggi lemak, serta 
memperbanyak mengkonsumsi sayur dan buah, dan melakukan aktifitas olah raga untuk mengurangi risiko terjadinya diabates mellitus.

3. Bagi peneliti lain perlunya diadakan penelitian yang lebih mendalam dalam bidang kesehatan tentang diabetes mellitus sehingga dapat mencegah terjadinya angka kesakitan.

\section{DAFTAR PUSTAKA}

Arisman. (2013). Buku Ajar Ilmu Gizi Obesitas, Diabetes Melitus, dan Dislipidemia Konsep, Teori dan Penanganan Aplikatif. Jakarta : EGC.

CDC. (2011). Centres For Disease Control and Prevention : National Diabetes Fact Sheet 2011. http://www.cdc.gov/diabetes/pubs/pdf/ndfs.2011.pdf.html. diakses tanggal 2 april 2017.

IDF. (2014). IDF Diabetes Atlas Sixth Edition. http://www.idf.org. Diakses Tanggal 10 Februari 2017.

Irawan, D. (2010). Prevalensi dan Faktor Risiko Kejadian Diabetes Melitus Tipe 2 di Daerah Urban Indonesia (Analisa Data Sekunder Riskesdas 2007). Tesis. Depok : FKM UI.

Kemenkes RI. (2014). Waspada Diabetes Eat Well Live Well. Jakarta : Infodatin 2014

Kementrian Kesehatan Republik Indonesia. (2013). Riset Kesehatan Dasar (RISKESDAS)

Tahun 2013. Diakses Tanggal 25 April 2017.

Manganti, A. (2012). Panduan Hidup Sehat Bebas Diabetes. Yogyakarta : Araska.

Maryunani, A. (2013). Diabetes pada Kehamilan. Jakarta : Trans Info Media.

Nurrahmani,U. (2012). Stop Diabetes Mellitus. Yogyakarta : Familia.

Ravangard, Sumadh,F. (2017). Early diabetis screening in obese women. Journal of maternalfetal and neonatal medicine. Volume 30. Number 5.

Susilo,y dan Wulandari,A. (2011). Cara Jitu Mengatasi Diabetes Mellitus (Kencing Manis). Yogyakarta : Andi.

Waspadji.S. (2015). Diabetes Mellitus, Penyakit Kronik dan Pencegahannya dalam Penatalaksanaan Diabetes Mellitus Terpadu Edisi Kedua. Editor : Soegondo.S., Soewondo.P., Subekti.I. Jakarta : Balai penerbit FKUI.

Yunir, Em dkk . (2015). Upaya Pencegahan Diabetes Tipe II. Jakarta : Balai Penerbit FKUI

Yunita B, Kurniawati E. (2016). Faktor Faktor yang Berhubungan dengan Kejadian Diabetes Mellitus Tipe II. Program sarjana Universitas Lampung. Majority. Volume 5. Nomor 2. 